zagrożonych niesprawiedliwym lub zbyt surowym wyrokiem, dotyczące obrony skazańców i azylantów, potwierdzając tym samym odpowiedzialność Kościoła za zgodny z zasadami chrześcijańskiej wiary kształt państwowego wymiaru sprawiedliwości. Do szczególnie znaczących osiągnięć Biskupa Hippony zalicza ks. Jóźwiak wypracowanie chrześcijańskiej nauki na temat kary śmierci, tortur, kar cielesnych czy też koncepcje wojny sprawiedliwej oraz wspólnej walki Kościoła i państwa z heretykami, które wywarły ogromny wpływ na późniejsze wieki.

Problemy ukazane w prezentowanej książce okazują się zagadnieniami aktualnymi także w czasach współczesnych i to nie tylko w wąskim gronie specjalistów, ale interesującymi szeroki krąg czytelników zastanawiających się nad własnym miejscem w Kościele i państwie. Wiele tematów podjętych w pracy jest przecież wciąż żywo dyskutowanych na forum opinii publicznej, ponieważ są ściśle związane z chrześcijańską etyką, a i samo zagadnienie państwa w ostatnim czasie również stało się przedmiotem publicznej debaty. Wydaje się, że podejmując te zagadnienia, należałoby wędrować po drogach intelektualnej refleksji z przewodnikiem - myślicielem, w dialogu z którym możne lepiej i głębiej przemyśleć podejmowane problemy. Warto więc rozpocząć tę przygodę ze św. Augustynem, a książka ks. Jóźwiaka jest doskonałym wprowadzeniem w myśl społeczno-teologiczną Biskupa Hippony.

Ks. Mariusz Terka - Częstochowa

\title{
Paweł JANISZEWSKI, The Missing Link. Greek Pagan Historiography in the Second Half of the Third Century and in the Fourth Century AD, The Journal of Juristic Papyrology Supplements VI, Warsaw 2006, David Brown Book Co., ss. XII + 531.
}

Badacze niechrześcijańskiej historiografii greckiej wieku III i IV w stopniu znacznie wyższym aniżeli pozostali filologowie klasyczni skazani są na korzystanie jedynie ze zbiorczych wydań testimoniów i fragmentów zachowanych przeważnie w późniejszej literaturze bizantyńskiej (Historici Graeci Minores, I-II, Lipsiae 1870-1871 - L. Dindorfa; Fragmenta Historicorum Graecorum, I-V, Parisiis 1853-1885 - K. Müllera; Fragmente der Griechischen Historiker, I-II, Berlin 1923-1930 - E. Jacobyego). Od dzieła Herodiana (Historia post Marcum Aurelium) przez kolejne półtora stulecia nie przetrwał w całości do naszych czasów żaden tekst historyczny (wyjątkiem jest tu XI mowa

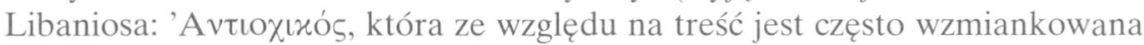
w opracowaniach historiografii. P. Janiszewski wykluczył jednak Libaniosa ze swojej syntezy, gdyż z założenia poświęcona jest ona twórczości nie zachowanej, ss. 291-292). 
Dodatkowo, jeszcze do połowy ubiegłego wieku powszechną w środowisku naukowym była opinia o niskiej wartości tej literatury. W klasycznej już i znakomitej skądinąd syntezie Stanisława Witkowskiego, Historiografja grecka i nauki pokrewne (I-III, Kraków 1925-1927), znajdziemy taki sąd: „Wszyscy najlepsi znawcy historiografji greckiej zgodni są dziś w tem, że twórczy okres jej rozwoju kończy się z czasami Augusta (...). Jeżeli w mem przedstawieniu poszedłem do III-go wieku po Chr. i uwzględniłem także epigonów, to uczyniłem tak dlatego, ze chodziło mi nie tylko o przedstawienie sił twórczych dziejopisarstwa, lecz i o oddanie poglądu na całość jego twórczości” (III, s. VI). Tak wielki uczony usprawiedliwia się z zamieszczenia charakterystyki Appiana, Arriana i Herodiana. Jeszcze silniejszy wydźwięk mają słowa: „W ogóle po II wieku po Chr. nie mamy w historiografji świeckiej żadnych uwagi godnych nazwisk!" (I, s. 11).

Takie nastawienie uczonych, wartościujących dorobek kulturalny wedle standardów epoki augustowskiej, szczęśliwie należy już do przeszłości. Od lat 60-tych (takim pierwszym zwiastunem zmian była synteza M.E. Colonny, Gli storici bizantini dal IV al XV secolo. I. Storici profani, Napoli 1956), zwłaszcza dzięki nowym odkryciom papirusowym oraz postępowi w krytyce tekstu, wzrasta zainteresowanie literaturą, która nie miała możliwości przetrwania. Być może jedną z przyczyn tego zjawiska jest fakt, iż właśnie wówczas, tj. na przełomie IV i V wieku dokonało się przejście ze zwoju do kodeksu; kopiowano wówczas w pierwszej kolejności i w największym nakładzie klasykę szkolną, a nie literaturę „współczesną”. Oczywiście nie znaczy to, iż dzieła III i IV-wieczne nie przetrwały, znali je przecież jeszcze uczeni średniobizantyńscy, jednakże ilość ich kopii była niewielka, nie miała charakteru masowego, a przez to miały one mniejszą szansę ocalenia.

W literaturze polskiej tematyka powyższa nie znalazła dotychczas należnego jej opracowania. W najnowszej syntezie historii literatury greckiej pod red. H. Podbielskiego (Literatura Grecji starożytnej, I-II, Lublin 2005) odpowiedni rozdział (K. Korus - Historiografia za cesarstwa, II, ss. 89-122) kończy się na omówieniu postaci Herodiana (ok. 178 - ok. 250). W trzecim uzupełnionym wydaniu Stownika pisarzy antycznych pod red. Anny Świderkówny (Warszawa $1990^{3}$ ), wzmiankowani są jedynie: Dexippos, Eunapios, Julian, Kasjusz Longinus, Libanios oraz Oreibasios. Należy przy tym zaznaczyć, iż w przypadku tego ostatniego nie wspomniano o twórczości historiograficznej, a w artykule poświęconym Kasjuszowi nie wymieniono przypisywanego mu autorstwa Kroniki. I to w zasadzie wszystko, poza krótkim, kilkunastostronicowym zarysem autorstwa Pawła Janiszewskiego w III tomie Vademecum historyka starożytnej Grecji i Rzymu (Warszawa 1999, ss. 14-32). Brak jest również studiów szczegółowych artykułów poświęconych konkretnym autorom. Dlatego Missing Link P. Janiszewskiego, jakkolwiek książkę angielskojęzyczną i przeznaczoną dla światowego kręgu specjalistów, należy uznać za dzieło w polskiej nauce pionierskie. 
Missing Link zawiera szkice o 50 autorach i 83 tytułach, co jest rzeczą imponującą, zważywszy na fakt, iż kilkoro z nich nie zamieścili w swoich wydaniach K. Müller czy F. Jacoby (należą do nich: Philagrios, ss. 121-123; anonimowy autor P.Oxy. LXIII 4352, ss. 228-235; Julianos z Cezarei Kapadockiej,

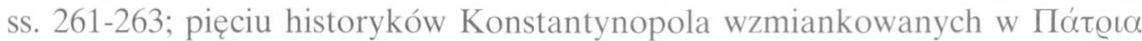

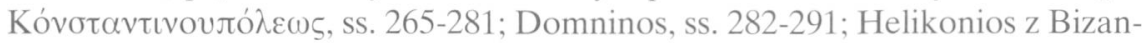
cjum, ss. 411-415). Podstawowym zamierzeniem Autora, była jak się wydaje, nie tyle synteza historii literatury pewnej epoki, co raczej krytyczny komentarz i uzupełnienie dla FGrHist, uwzględniające blisko stuletni dorobek filologów. Stąd wyniknął podział materiału ze względu na cechy gatunkowe, a w dalszej kolejności na wysoce erudycyjne studia nad każdą postacią i utworem. Materiał podzielony został na cztery rozdziały, poprzedzone wstępem (ss. 3-26) i zakończone podsumowaniem (ss. 431-464), obszerną bibliografią (ss. 465-526) oraz indeksem (ss. 527-532). Pierwszy rozdział zatytułowany „Political Historiography” (ss. 27-164) składa się z trzech mniejszych całości: „Universal Histories” (ss. 27-84), „Contemporary Histories” (ss. 85-143), „Histories of early periods only” (ss. 144-164). Rozdział następny, „Local Historiography” (ss. 165-328) podzielony jest już tylko według przypuszczalnej chronologii powstania utworów. Rozdziały następne: „Histories and Biographies of Emperors” (ss. 329-394) oraz „Chronography” (ss. 395-422) nie mają już podziałów wewnętrznych. Po rozdziale czwartym umieszczony jest apendyks (ss. 423-430), zawierający spis greckich i łacińskich historyków wzmiankowanych w Historia Augusta wraz z odniesieniem do ich ewentualnej znajomości z innych źródeł, co nie jest możliwe we wszystkich przypadkach.

Rzut oka na spis rozdziałów wskazuje nam, iż podział materiału ma mieszany, tematyczno-gatunkowy charakter. Rozdziały pierwszy i drugi zostały utworzone w kategoriach uwzględniających zawartość treściową, rozdział zaś czwarty ze względu na cechy gatunkowe. Ciekawą kwestią jest rozdział 3: „Historie i biografie cesarzy” (ss. 329-394). Ponieważ zamieszczone w nim utwory dotyczą Galiena, Konstantyna czy Juliana, to równie dobrze mogą one być zamieszczone w podrozdziale pt. „Contemporary Histories” rozdziału pierwszego, zwłaszcza, że Autor umieścił w nim np. teksty poświęcone perskiej ekspedycji Juliana (ss. 113-144). Można zatem przypuszczać, iż za decyzją o takim wydzieleniu rozdziału trzeciego zadecydowała chęć P. Janiszewskiego zaznaczenia pewnej odrębności gatunkowej, reprezentowanej przez bioi (vitae). Jednakże w sytuacji, gdy posiadamy tak mało informacji o tekście, a w najlepszym razie jedynie kilkuzdaniowe fragmenty, trudno mówić o jednoznacznej klasyfikacji gatunkowej.

W takiej konstrukcji książki stało się rzeczą oczywistą, że historycy, którzy byli autorami dzieł zróżnicowanych gatunkowo, będą omawiani wielokrotnie. I tak np. twórczość Dexipposa z Aten pojawia się trzykrotnie w rozdziale pierwszym, ale w osobnych podrozdziałach. Z kolei Soterichosa z Oasis znaj- 
dziemy w dwóch różnych rozdziałach: pierwszym i drugim, podobnie Praksagorasa $z$ Aten, który omawiany jest w rozdziale pierwszym, drugim i trzecim. Konsekwencją prymatu charakterystyki utworu nad sylwetką jego autora jest natura Missing Link. Książka ta jest przez to nie tyle syntezą, historią literatury greckiej pewnego okresu, co raczej zbiorem analitycznych studiów pełnych filologicznej akrybii. Przy prezentacji historyków i ich dzieł Autor niejednokrotnie przeprowadza szczegółowe studia prosopograficzne. Tak jest np. w przypadku Asiniusa Quadratusa, Dexipposa, Soterichosa z Oasis, Seleukosa z Emesy, Horapollona, Onasimosa. Ich obecność to jedna z ważnych zalet książki.

W tak szeroko zakrojonej, erudycyjnej pracy, pewne błędy są rzeczą naturalną, dlatego, choć pominąć należy drobne błędy drukarskie (a jest ich kilkanaście), to nasuwają się natomiast, wynikłe poniekąd z lektury, zagadnienia.

Przy prezentacji sylwetki Apiona z Aleksandrii (s. 413) zabrakło informacji, iż jest on tożsamy z adresatem dzieła Józefa Flawiusza: Contra Apionem. U czytelnika, który dopiero zaczyna poznawać literaturę grecką mogło powstać wrażenie, że są to postaci odrębne. I jeszcze jedna uwaga odnośnie Apiona. Otóż wymienione przez P. Janiszewskiego jako odrębne utwory:

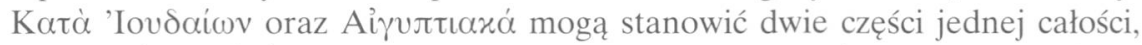

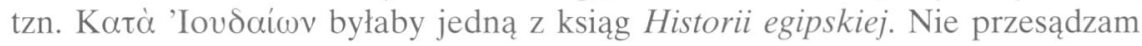
tutaj tej kwestii, związanej głównie z interpretacją wypowiedzi Klemensa z Aleksandrii (Stromata I 101, 3), a jedynie zaznaczam, iż istnieje spór wokół charakteru historiograficznej twórczości Apiona.

Innym interesującym zagadnieniem jest wpływ twórczości Praksagorasa z Aten na historiografię chrześcijańską. Paweł Janiszewski na blisko dwudziestu stronach (ss. 352-371) wyczerpująco zaprezentował jego sylwetkę i twórczość. Można w związku z tym postawić pewną hipotezę: czy Euzebiusz z Cezarei przy pisaniu Vita Constantini mógł korzystać z dzieła Praksagorasa Historia Konstan-

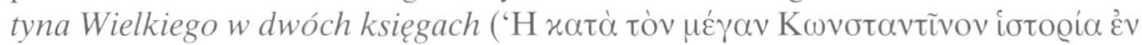
$\beta$ « $\beta$ íoıs $\beta$ )? Według Janiszewskiego tekst ten powstał ok. 325 r., Euzebiusz zaczął zbierać materiały do swego utworu przynajmniej na początku lat trzydziestych, mógł zatem skorzystać z lektury Ateńczyka. Z obrazu nakreślonego przez Focjusza (cod. 62) wynika, iż pod względem gatunkowym Historia Konstantyna mieściła się na pograniczu między bios (vita), a enkomionem (panegyricus), identycznie jak Vita Constantini Euzebiusza, którego też nie da się jednoznacznie przyporządkować gatunkowo. Co ważne zachodzą również pewne podobieństwa w treści: a) charakterystyka postaci Konstancjusza; b) argumentacja o legalnym objęciu władzy przez Konstantyna po śmierci ojca w Eburacum, choć w rzeczywistości było to złamanie zasad tetrarchii; c) tłumaczenie późniejszej wojny domowej jako wojny z tyranami w obronie libertas. Wszystkie te przesłanki pozwalają na uzasadnione przypuszczenie, iż Euzebiusz znał i naśladował w pewnym stopniu dzieło Praksagorasa. 
Na odrębną uwagę zasługuje bibliografia. Godną komentarza jest przebogata literatura przedmiotu, odzwierciedlająca postęp w badaniach filologicznych i prosopograficznych oraz wykaz wydań krytycznych każdego, wzmiankowanego w tekście autora. Tutaj też można by wnieść pewne uzupełnienia. Otóż w przypadku Homera (s. 478) P. Janiszewski podaje wydanie u Loeba z lat 1924-1925 (repr. 1999), tymczasem za tekst reprezentatywny uznaje się edycję T.W. Allena w OCT (Homeri Opera, Oxford 1912 i późniejsze dodruki). Dodatkowo w ostatnich latach doszło w badaniach nad Homerem do ważnego wydarzenia, jakim była dwutomowa, nowatorska edycja Iliady u Teubnera, autorstwa Martina Westa w latach 1998-2000. Wydaje się zatem rzeczą pożądaną, aby bieżące i przyszłe prace, cytujące poematy Homerowe, opierały się na tych wydaniach.

Praca więc The Missing Link Pawła Janiszewskiego ze względu na swą erudycję oraz antykwaryczną dokładność, to nie tylko próba rekonstrukcji utraconego stadium w historii literatury greckiej i swoiste uaktualnienie dzieła F. Jacoby'ego, ale stanowi również nowy punkt odniesienia w badaniach nad historiografią greckojęzyczną III-IV stulecia.

Anna Kotłowska - Poznań, UAM

\section{Sławomir BRALEWSKI, Obraz papiestwa w historiografii kościelnej wczes- nego Bizancjum, Byzantina Lodziensia X, Łódź 2006, Wydawnictwo Uniwer- sytetu Łódzkiego, ss. 334.}

Wieloletnie badania S. Bralewskiego nad związkami Kościoła i państwa bizantyńskiego w IV-VII wieku zaowocowały szeregiem poważnych studiów, które przysporzyły Autorowi uznania w kręgach specjalistów w Polsce i poza jej granicami. W tych badaniach musiał on uwzględnić fakt, iż Kościół Powszechny tych czasów nie stanowił pod względem organizacyjnym monolitu, że interesy wiodących stolic biskupich bywały często rozbieżne, że pogłębiał się coraz wyraźniej podział na Kościół Wschodni i Zachodni oraz, że niekwestionowana na Zachodzie dominująca pozycja biskupa Rzymu bywała inaczej widziana w pars Orientis. Rozpatrzeniu tego ostatniego właśnie problemu S. Bralewski poświęcił książkę, która jest przedmiotem niniejszej recenzji.

Otwiera ją obszerny rozdział wstępny (ss. 9-24), który omawia pozycję biskupa Rzymu w ideologii Zachodu, wypracowanej pomiędzy I a VI wiekiem, a następnie charakteryzuje główne źródła rozważań Autora, a mianowicie Historie kościelne napisane przez Euzebiusza z Cezarei, Sokratesa Scholastyka, Hermiasza Sozomena, Teodoreta z Cyru i Ewagriusza Scholastyka, by w końcu odnieść się do dotychczasowego dorobku nauki światowej w omawianych kwestiach. 